\title{
IKAN PAIS (THE ECOLINGUISTIC ANALYSIS OF A TRADITIONAL BENGKULUNESE CUISINE)
}

\author{
Nopriansah. University of Dehasen Bengkulu \\ nopriansahad@gmail.com
}

\begin{abstract}
Abstrak
Pentingnya bahasa dalam hubungannya dengan lingkungan dan budaya menjadikan bahasa sebagai unsur penting dalam penelitian lingkungan alam dan sosial. Berbicara mengenai budaya dan alam dalam kajian Ekolinguistik tidak lepas dari local genius yang menjadi kekayaan suatu bangsa termasuk dalam hal ini adalah kuliner tradisional yang secara sengaja (culturally) atau tidak disengaja (naturally) memiliki keterkaitan dengan alam sekitar yang melingkupi suku/bangsa pembuat kuliner tersebut. Salah satu kuliner tradisional asal Bengkulu, yaitu Ikan Pais menjadi salah satu bentuk budaya setempat (local genius) yang terwujud dari penggunaan beberapa benda lainnya berhubungan dengan lokasi pembuatan kulinerter sebut. Penulis mengangkat topic Ikan Pais sebagai local genius dalam penelitiannya yang dianalisis menggunakan sudut pandang Ekolinguistik. Penelitian ini bertujuan untuk memberikan deskripsi yang lengkap dan sahih tentang bentuk, makna, fungsi, dan nilai yang terkandung dalam benda-benda local genius kuliner tradisional Ikan Pais. Penelitian ini mengacu pada teori-teori linguistic umum dan Ekolinguistik yang berhubungan dengan bentuk, makna, fungsi, dan nilai, antara lain teori yang dikemukakan oleh Chomsky (dalam Van Valin dan La Polla (1997), Lyons (dalam Djajasudarma, 2009), Suryadi et al (2002), Edward Sapir, Peter Finke, dan Einar Haugen (dalam Fill dan Mühlhaüsler, 2001), serta berbagai pandangan lain yang mempunyai korelasi dengan penelitian ini. Metode yang digunakan dalam penelitian ini adalah metode cakap, metode simak, dan metode kepustakaan. Metode cakap adalah percakapan dan terjadi kontak antara peneliti selaku peneliti dengan penutur selaku nara sumber. Metode simak adalah penyimakan terhadap bahasa yang digunakan (Sudaryanto, 1988). Sedangkan metode kepustakaan adalah pengumpulan data dengan mengadakan studi penelaahan terhadap buku-buku, literatur-literatur, catatan-catatan, dan laporan-laporan yang ada hubungannya dengan masalah yang dipecahkan (Nazir dalam Agung, 2011). Dengan demikian, hasil yang diharapkan adalah berupa pemerian terhadap aspek tersebut dipandang dari disiplin Ekolinguistik.
\end{abstract}

Keywords: Ikan Pais, Local Genius, Ekolinguistics

\section{INTRODUCTION}

\subsection{Background}

In ecolinguistics, it is hyphotesized that language can be influenced by the environment (as cited in Sapir in Fill and Mühlhaüsler, 2001). Meanwhile, in anthropolinguistic studies, language is seen as one of the cultural riches of a tribe/people as well as other cultural elements, namely the religious system, the system of community organizations, knowledge systems, livelihood and economic systems, technological systems and equipment, and art (as cited in
Koentjaraningrat in Haruman, 2008). The importance of language in relation to this environment and culture makes language an important element in both different but interconnected disciplines. Whereas, Finke (as cited in Fill and Mühlhaüsler, 2001) states that culture is part of nature. There is a significant relationship between the two variables; culture can affect nature or rather the culture is influenced by nature.

Talking about culture and nature in ecolinguistic studies can not be separated from 
local genius which is the wealth of a civilization including, in this case, a traditional cuisine that intentionally (culturally) or unintentionally (naturally) has a connection with environment that surrounds the tribe/people of the maker. The existence of special lexicons that the referents are in the form of cultural objects in a tribe/people is the evidence that language, culture and natural environment have a synergistic relationship. For this reason, researchers provide an example of special lexicons in naming one of traditional cuisines from Bengkulu (especially from the west coast of Bengkulu City). The cuisine is Ikan Pais which is made from several objects related to the location that the cuisine original makers live.

Linguistic research on the traditional cuisine of Ikan Pais has never been done, especially one that is viewed from ecolinguistic disciplines. Instead of analyzing the closeness of the phonological aspects of Pais/pais/ and pies /paiz/, the author raised the topic of Ikan Pais as a local genius in his research which was analyzed using an ecolinguistic point of view.

The results of this study are expected to add to the repertoire of the study of forms, meanings, functions, and values, especially in the ecolinguistics and can be used as a material for the study of relations of a languageto others. The result of this study can surely be useful for the development of linguistics in Indonesia.

\subsection{Problems}

The problem discussed in this study is an object that isa local genius, which names and uses are influenced by the environment, origin from the city of Bengkulu, especially from the west coast region of Bengkulu, namely Ikan Pais. Local genius itself is the identity of culture which causes the people to be able to absorb and process foreign culture according to its own character and abilities, including in this case the identity of traditional cuisine that is still preserved.

The aspects examined in the traditional cuisine are as follows:

1. Form, covering the whole form as a lexicon;

2. Meanings, including the lexicon which forms a lexical meaning;

3. Functions, including noun forming functions;

4. Value, including the artistic value of local genius named Ikan Pais, the cultural ecosystem and the additional value of the Ikan Pais song lyrics that use the local genius lexicons.

\subsection{Purpose}

This study aims to provide a complete and valid description of the forms, meanings, functions, and values contained in the traditional culinary genius of Ikan Pais. Thus, the expected results are in the form of an examination of these aspects viewed from the ecolinguistic discipline.

\section{THEORETICAL FRAMEWORK}

This study refers to general and ecolinguistic linguistic theories that relate to form, meaning, function, and value, including the theory put forward by Chomsky (in Van Valin and LaPolla (1997), Lyons (in Djajasudarma, 2009), Suryadi et al (2002), Edward Sapir, Peter Finke, and Einar Haugen (in Fill and Mühlhaüsler, 2001), as well as various other views that have correlation with this study.

\subsection{The Forms of Ikan Pais}

In studying linguistic structures, the term of phrase is necessarily discussed. Phrases can only consist of one main (head) and one 
explanatory word (modifier) (as cited in Chomsky in Van Valin and LaPolla, 1997). An example of the phrase in this study is the name of a cuisine that the origin is from the city of Bengkulu, especially from the west coast region of Bengkulu, namely Ikan Pais. The phrase of <ikan pais>consists of one head, namely <ikan> and one modifier, <pais>. There are still many phrases that become local geniuses in the making process of the traditional "fish pies" discussed in the next chapter.

\subsection{The Meaning of Ikan Pais}

Reviewing or giving meaning to a word is understanding the study of words that relates to the meaning relations that make a word different from other (as cited in Lyons in Djajasudarma, 2009: 7). Based on this theory, researcher provided meanings by examining and understanding information relating to each local genius object used in the making process of the traditional cuisine.

\subsection{The Functions of Ikan Pais}

Suryadi et al (2002) explained that the function of a linguistic form including phrases is named according to the categories they produce. Based on this limitation, the function that produces a verb is called a verbal function, a function that produces a noun is called a nominal function, a function that produces an adjective is called an adjectival function, and a function that produces adverbial is called an adverbial function. In this study, the nominal function or function that forms the noun to become the subject of discussion. The function is derived from objects or nouns used in the making process.

\subsection{The Values of Ikan Pais}

Ecolinguistics begins with metaphor (as cited in Fill in Fill and Mühlhaüsler, 2001: 43). Metaphor is a linguistic art that can be used in naming something that is influenced by the environment (as cited in Haugen in Fill and Mühlhaüsler, 2001). Based on this limitation, researchers analyzed the artistic value of naming objects used in the making process of traditional cuisine Ikan Pais metaphorically. The names of these objects can be derived from the characteristics inherent in the type of living thing in question or symbolize a particular meaning metaphorically in one other meaning.

\section{METHODS AND TECHNIQUES}

The methods used in this study wereobservation, referring,reading, and literature reviewing. The observation wasdone by getting involved in conversation and contact occured between the researcher and the speaker as the resource person. The referring method is listening to the language used (as cited in Sudaryanto, 1988). While the literature reviewing is the data collection by conducting studying of books, literature, notes, and reports that have to do with the problem being solved (as cited in Nazir in Agung, 2011). While the techniques used are advance proficiency techniques, competent involvement of free listening techniques, and note-taking techniques (cf: Sudaryanto 1988 and Nazir in Agung, 2011).

The advance proficiency technique is a direct or prominent conversation activity. In this case, the researcher provoked the talk of the resource persons when they made Ikan Pais. Conversations are controlled by researchers and directed according to their interests, namely obtaining data as many as the desired data type 
or expected to exist. The other technique used by researchers is the skillful free-seeing technique. With this technique, the researcher listened to the Bengkulu folk song entitled Ikan Pais and then recorded the desired data. The last technique used is the note-taking technique with respect to the literature reviewing. For this technique, the author recorded data obtained from his activities visiting the library on line with the address http://novandirezeki.blogspot.com/ 2018/12/liriklagu-ikan-pais-lagu-daerah.html.

\subsection{Research Data}

The data classified in this study are the oral and written language data obtained by applying the observational method, seeing and reviewing literature. Oral data were obtained by applying the competent method with informants who were native speakers of Bengkulu in the early 2000s. This informant is a 70-year-old woman named Asni who is also the grandmother of the researcher. Oral data were also obtained from the results of listening to a Bengkulu folk song entitled Ikan Pais which was created by Darus Nachrowi and sung by a woman whose name was unknown onhttp://www.youtube.com/ watch?V=YzUG0EFtjGA dated August 20, 2018. For writing data, researchers get them when looking for additional information about the traditional cuisine of Ikan Pais and Bengkulunese regional song lyrics entitled Ikan Pais by accessing the library on line with the addresshttp://novandirezeki.blogspot.com /2018/12/lyrics-lagu-ikan-pais-lagu-daerah.html. on August 20, 2018.

To analyze the selected data, the researcher used the matching method and the technique to divide the determinants with the power to divide as a reference reference.
Sudaryanto (1993: 22) said that to divide the lingual units of words into various types, the difference between referents must be known in advance; and to find out the difference between the referents, the mental dividing power possessed by the researcher must be used. In this study the referent referred to is a noun or noun forming a classification in the Ikan Pais cultural ecosystem which is specifically displayed in italic letters and followed by its meaning in Indonesian.

\subsection{Traditional Cuisine of Ikan Pais \\ 3.2.1. History of Making Ikan Pais}

The city, as well as the province, of Bengkulu is one of cities in Indonesia. The city has an area of $151.7 \mathrm{~km}^{2}$ with 3 types of topography of the region, namely hills of $>10$ meters above sea level, lowlands of 5-10 meters above sea level, and coastal areas of 0-5 meters above sea level. In the coastal area, which is located in the western part of the city, settle the indigenous people of Bengkulu and migrants. The mixing of cultures between indigenous people and migrants is certainly unavoidable as it is the characteristics of an urban area. However, in the midst of the strong external cultural influences that had come into the lives of the indigenous people of Bengkulu, especially the people in the west coast region, there were several elements of indigenous culture that now persist as local geniuses. The surviving cultural elements are more related to language systems, knowledge systems, economic systems/ livelihoods, technology and equipment systems, and art. One proof of the survival of the five systems is still known and made some traditional cuisine in the city of Bengkulu.

There are various traditional cuisines in the city of Bengkulu. One of them, especially 
made in the west coast region of Bengkulu City, is the Ikan Pais. It is a traditional cuisine made by the indigenous people of the west coast of Bengkulu City. The topography of Bengkulu City which has a coastal area strongly supports the creation of ideas and survival of the making of the local genius.

No one knows certain history of the making of Ikan Pais; when it was made and who firstly made it until now is not yet known. However, what is clear is that the informant said that the knowledge of recipes and methods for making Ikan Pais which she obtained was passed down from generation to generation directly from mouth to mouth without any written documentation. Only in the last few decades have the recipes and methods of making traditional culinary been documented in writing in several cooking books and personal blogs observing traditional Indonesian cuisine.

The loss of some information about the history of making Ikan Pais is a matter of concern. Local genius that should be the wealth of the people of Bengkulu City has become endangered or even been potentially claimed by other nations as their cultural heritage. This problem can be minimized by holding ecolinguistic research on one of the many riches of traditional cuisine in Indonesia. By applying research methods and ecolinguistic theory, everything (in this case the nouns) is formally classified in Ikan Pais cultural ecosystem.

Ikan Pais cultural ecosystemis all material (physical) and nonmaterial (psychic) elements that make up a system in an ecology or cultural environment along with its cultural objects (Finke in Fill and Mühlhaüsler, 2001). Based on this theory, a number of objects (nouns) collected are lexicons in the native language of the people inthe west coast of Bengkulu City. They are classifiedbased on theforms, meanings, functions, and values in connection with the traditional cuisine ofIkan Pais.

\subsubsection{Tools, Materials, and The Way How to Make Ikan Pais}

a. Tools

The tools used in making Ikan Paisare:

1. cambung 'bowl'

2. piring'plate'

3. parutan kelapo'coconut grater'

4. pisau'knife'

5. batu giling'milled stone'

6. sendok'spoon'

7. panci'pan'

8. daun pisang jantan 'banana leaf'

9. tali mesiang 'rope from pandan leaf'

\section{b. Materials}

The following ingredients are needed in making Ikan Pais:

1. ikan capa'a type of sea fish' $200 \mathrm{~g}$

2. daun talas 'taro leaves'15 sheets

3. kelapo mudo'young coconut flesh' $250 \mathrm{~g}$

4. kelopo tиo' old coconut flesh' $250 \mathrm{~g}$

5. bawang mera 'onion' 4 heads

6. -bawang puti 'garlic' 2 heads

7. cabe mera 'Red chillies' $80 \mathrm{~g}$

8. sepede 'ginger' $40 \mathrm{~g}$

9. lengkue'galangal' $40 \mathrm{~g}$

10. kunyit 'Turmeric'40 g

11. daun kemangi 'basil leaves'5 pieces

12. daun jeruk purut 'kaffir lime leaves' 3 pieces

13. daun kunyit 'turmeric leaves' 2 pieces

14. garam 'salt' as needed

15. gulo 'sugar' as needed

16. air asam jawa 'Tamarind water'as needed

17. air 'water for boiling' 
18. jering mudo 'kind of fruit, A. paucilorum' as needed

\section{c. The Way of Making Ikan Pais}

The process of making Ikan Pais is as follows:

1) Grate kelapo tuo 'old coconut flesh', roast then puree it;

2) Grate kelapo mudo (half ripe) then puree it;

3) Mix the two ingredients above into cambung 'bowl' and mix with bawang mera 'onion', cabe mera 'red chili', bawang puti 'garlic', sepede 'ginger', lengkue 'galangal', kunyit 'Turmeric', daun kemangi 'basil leaves', daun jeruk purut 'kaffir lime leaves', and daun kunyit 'turmeric leaves' which have been ground with batu giling 'milled stone';

4) Add garam 'salt', gulo'sugar' and air asam jawa 'tamarind water'as needed;

5) Put the cleaned ikan capa 'a type of sea fish' into the spices that have been prepared;

6) Wrap the fish and spices with 15 daun talas 'taro leaves', arrange them in layers;

7) Coverthe row Ikan Pais with daun pisang jantan 'banana leaf' and tie them with tali mesiang 'rope from pandan leaf';

8) Boil air 'water' in panci 'pan' and mixit with air asam jawa 'tamarind water' then boil the package of row Ikan Pais in the pan. Try to cover all of the package withair 'water';

9) Wait until cooked (about 2 hours to be really soft), lift and serve on piring 'plate';

10) Add some jering mudo 'kind of fruit, $A$. paucilorum' as the garnish that can also be eaten together with the cooked Ikan Pais.

\subsection{Bengkulunese Traditional Song Entitled Ikan Pais}

The song entitled Ikan Pais is a traditional song from the City of Bengkulu. This song tells the process of making and enjoying the taste of the traditional cuisine. The following is the song lyricthat was created by Darus Nachrowi.

\section{Title: Ikan Pais}

Ikan pais, lemak rasonyo

Makan kek nasi putih paneh-paneh

Ulam kek jering mudo

Ikan pais, kelaponyo mudo

Dibungkus daun talas rapi-rapi

Kebek kek tali mesiang

Rasonyo oii lemak nian

Badan keringek rintik-rintik

Nasi sepiring sudah habis, raso ndak tambuh

Rasonyo oii lemak nian

Badan keringek rintik-rintik

Sambalnyo pedeh tambuh lagi, habis segalo

Source:

http://novandirezeki.blogspot.com/2012/12/lirik-

lagu-ikan-pais-lagu-daerah.html

The following is the translation of the lyric in English:

Ikan Pais, it tastes delicious

Eaten with hot white rice

completed with fruit named $A$. paucilorum

Ikan Pais, the coconut is young

Wrapped in taro leaves neatly

tied withrope of mesiang

The tasteis wowvery delicious

Our bodies will sweat like the rain

A plate of rice has been eaten, we'll ask for another plate

The taste is wow very delicious

Our bodies will sweat like the rain

The sauce is so hot and we'll ask for another plate, all is completely used up 


\section{THE ANALYSIS OF TRADITIONAL CUISINE OF IKAN PAIS THROUGH ECOLINGUISTIC APPROACH}

In explanation above, there are 27 lexicons that are italicized and followed by their meanings in English. These lexicons are objects in the original language of the west coast of Bengkulu City which are spoken by informants. The lexicons are:

1) cambung 'bowl'

2) piring 'plate'

3) parutan kelapo 'coconut grater'

4) pisau 'knife'

5) batu giling 'milled stone'

6) sendok 'spoon'

7) panci 'pan'

8) daun pisang jantan 'banana leaf'

9) tali mesiang 'rope from pandan leaf'

10) ikan capa 'a type of sea fish'

11) daun talas 'taro leaves'

12) kelapo mudo 'young coconut flesh'

13) kelopo tuo 'old coconut flesh'

14) bawang mera 'onion'

15) bawang puti 'garlic'

16) cabe mera 'Red chillies'

17) sepede 'ginger'

18) lengkue 'galangal'

19) kunyit 'Turmeric'

20) daun kemangi 'basil leaves'

21) daun jeruk purut 'kaffir lime leaves'

22) daun kunyit 'turmeric leaves'

23) garam 'salt'

24) gulo 'sugar'

25) air asam jawa 'Tamarind water'

26) air 'water for boiling'

27)jering mudo 'kind of fruit, A. paucilorum'

These lexicons or objects form a classification in Ikan Pais cultural ecosystem. As many as 5 of the 27 objects are the key lexicons in Ikan Paisculture ecosystem. The five objects are:

1) tali mesiang 'rope from pandan leaf'

2) ikan capa 'a type of sea fish'

3) daun talas 'taro leaves'

4) kelapo mudo 'young coconut flesh'

5) kelopo tuo 'old coconut flesh'

By only hearing the five lexicons contained in the classification above, the people of Bengkulu City can straightly interpret that the food made is Ikan Pais, they will not think about rendang, satay, soup, or others.

These five lexicons, followed by their use in Ikan Pais culture ecosystem, are also local objects or nouns because they are used by the people of west coast of Bengkulu City to make Ikan Pais. The five local geniuses, through ecolinguistic approach are analyzed as follows:

1) tali mesiang 'rope from pandan leaf'

a. Form, including the whole form as a phrasewhich consists of two lexicons, namely tali as a head and mesiangas a complement;

b. Meaning, including two lexicons of tali mesiang that form a grammatical meaning, namely a rope made of pandan leaves which is a local genius of the people on the west coast of Bengkulu City;

c. Function, includinga compound noun forming a function consisting of two lexicons in one noun phrase which is the local genius of the people on the west coast of Bengkulu City, used for tying up something;

d. Value, including the value of art of local genius on the west coast of Bengkulu City.It is a native language of the people. The use of names and objects in the form of tali mesiang in the traditional cuisine of 
Ikan Pais gives the impression that the cuisine is the result of a unique creation.It has a different name from other regions. In addition, if associated with Ikan Pais song lyrics, the word mesiang coherently supports the idea and aesthetic value of the folk song.

The linguistic features of tali mesiang significantly relates to the ecosystem surrounding. The unique local genius is made from the leaves of pandanus plants that grow in the west coast of Bengkulu City. Naturally, pandanus plants (Pandanus tectorius) grow in coastal areas with an altitude of 0-610 meters above sea level (Hadi, 2013). The west coast of Bengkulu City is an ideal habitat for this plant because it has a height of 0-5 meters above sea level. However, over time, the role of tali mesiang as a tie for eco-friendly Ikan Pais package is increasingly substitutedwith the presence of plastic straps. In addition, the land where pandanus grows naturally decreases due to the construction of an integrated tourism area in the west coast of Bengkulu City.

\section{2) Ikan Capa 'a type of sea fish'}

a. Form, including the whole form as a phrase which consists of two lexicons, namely Ikan as a head and Capa as a complement;

b. Meaning, including two lexicons of Ikan Capa which form a grammatical meaning, which is a type of sea fish that can be used in making traditional cuisine of Ikan Pais,cooked with spices, wrapped with taro leaves and banana leaves. Ikan Capa along with how to use it is a local genius of the people on the west coast of Bengkulu City;

c. Function, including a compound noun forming a function consisting of two lexicons in one noun phrase which is the local genius of the people on the west coast of Bengkulu City;

d. Value, including the value of art of local genius named by people on the west coast of Bengkulu City. The use of name and ingredient in the form of Ikan Capa and processing the fish along with spices gives the impression that the cuisine is the result of unique creation of the west coast people of Bengkulu City.

Like tali mesiang, the linguistic features of ikan capaalso significantly relates to the ecosystem surrounding. The unique local genius'habitat is marine waters. The west coast of Bengkulu City is an area located on the seafront, precisely Samudera Indonesia. At present the fishermen on the west coast of Bengkulu City are still able to catch fish in these waters and Ikan Capa are still found because the way fishermen catch fish is still traditional, not using trawlers or bombs that can damage fish habitat.

3) daun talas 'taro leaves'

a. Form, including the whole form as a phrase which which consists of two lexicons, namely daun as head and talas as a complement;

b. Meaning, including two lexicons of daun talas that form grammatical meaning, namely taro leaves that can be used in making traditional Ikan Pais by cooking in layers covering the fish with spices. Taro leave along with the way they are used isa local genius of the west coast of Bengkulu City;

c. Function, including a noun forming a function consisting of two lexicons in one 
noun phrase which is the local genius of the people on the west coast of Bengkulu City;

d. Value, including the value of artof local genius in naming athing which is a loan phrase (from Bahasa Indonesia). The use of name and ingredients in the form of daun talas gives the impression that the cuisine of Ikan Pais is the result of unique creation of the west coast people of Bengkulu City.

This daun talas significantly relates to the ecosystem surrounding. The unique local genius are actually leaves of taro plants (Araceae). In Indonesia, taro can be found in almost all islands and spread from the coast to the mountains above 1000 meters above sea level, both wild and planted. The type of taro that is usually used in making traditional Ikan Pais is talas sutera (silk taro) that has light green leaves and very fine hairy like silkworms (Wardiyono, 2014). Taro leaves along with the way they are used are local geniuses of the west coast of Bengkulu City. In making Ikan Pais, taro leaves are cooked in layers arranged in capa and then boiled for as long as possible (about 2 hours) to make them really soft even for the bones. This is done in addition to shape the texture of easily digestible foods as well as to eliminate the itchy content of taro leaves. This process is unique to make taro leaves along with Pais Fish as a local genius of the people on the west coast of Bengkulu City.

4) kelapo mudo 'young coconut'and 5) kelapo tuo 'old coconut'

a. Form, including the whole forms as two phrases which are local geniuses of the west coast of Bengkulu City, which consists of four lexicons, namely kelapo as the head and mudo as the modifier and kelapo as the head and tuo as the modifiers; b. Meaning, includes four lexicons in two phrases kelapo mudo and kelapo tuo which form a grammatical meaning that is kelapo mudo, which is half ripe coconut meat (not too young and not too old) and kelapo tuo, which is old coconut meat.

c. The function includes the noun forming function consisting of four lexicons in two noun phrases which are local geniuses of the west coast of Bengkulu City, namely kelapo mudo and kelapo tuo;

d. The value includes the art value of local genius naming, namely kelapo mudo and kelapo tuo, which are the native languages of the west coast of Bengkulu City. The use of names and ingredients in the form of kelapomudo and kelapo tuo simultaneously in one dish of Ikan Pais gives the impression that the culinary is the result of the unique creation of the people of Bengkulu City.

Coconut fruit is a fruit from a coconut plant (Cocos nucifera) that grows well in hot and humid climates, namely in coastal areas up to 500 meters above sea level (Palma Crops Research Institute, 2010). The west coast of Bengkulu City is an ideal area for growing and developing coconut trees. However, as with pandanus plants, the land where coconut trees grow is also decreasing due to the construction of integrated tourism areas in the west coast of Bengkulu City.

The five objects as local genius above are integrated with the use of spices mentioned in Sub-Section 2.2.2 and processed in the manner described in Sub-Section 2.2.3 into a culinary is a physical and non-physical component forming a unique cultural ecosystem that creates a 
traditional culinary community of the west coast city of Bengkulu named fish Pais.

In addition to analyzing the oral data obtained by the observation as mentioned above, the researcher also analyzed the oral data by using the listening method with the technique of listening to a Bengkulu regional song entitled Ikan Pais created by Darus Nachrowi and sung by a woman whose name was not known at the address

http://www.youtube.com/watch?v=YzUG0EFtjG A on December20, 2018.

The data obtained by the researcher with the reading method if written down will have the same form and meaning as the written data obtained by the researcher with the literature method. In the Ikan Pais song lyrics (See Section 2.3) there are several items that are the same as those mentioned by the informant in the research using the proficient method and see above. These objects are:

1. tali mesiang 'rope from pandan leaves'

2. daun talas 'taro leaves / taro'

3. kelapo mudo 'young (half ripe) coconut

4. jering mudo 'kind of fruit, A. paucilorum'

These objects, as previously described, form a classification in the Ikan Pais cultural ecosystem. Metaphorically, the word mesiang in the song symbolizes one other object, namely Ikan Pais, and the song Ikan Pais symbolizes the culture of the coastal community of Bengkulu City, especially traditional culinary which is a local genius.

\section{CONCLUSION AND SUGGESTION}

\subsection{Conclusions}

There are 11 objects in the original language of the west coast of Bengkulu City which are classified into the Ikan Pais cultural ecosystem in the form of lexicons/noun phrases. These lexicons/phrases are cambung'bowl', batu giling 'milled stone', tali mesiang 'rope from pandan leaves', capa 'sea fish', daun talas 'taro leaves', kelapo mudo 'young coconut (half ripe)', kelapo tuo 'old coconut', sepede 'ginger', lengkue 'galangal', gulo'sugar', and jering mudo 'kind of fruit, A. paucilorum'.

Five of the 11 objects are key lexicons/phrases as well as local geniuses in the Ikan Pais cultural ecosystem. The five objects are tali mesiang 'rope from pandan leaves', capa 'sea fish', daun talas 'taro leaves', kelapo mudo 'young coconut (half ripe)', kelapo tuo 'old coconut'.

Ikan Pais, both generally as a culinary name and specifically made of objects that have been analyzed from the ecolinguistic point of view above, become local geniuses and identities for the city of Bengkulu, especially in the west coast. The same type of cuisine has a different name in the southern region of Bengkulu Province. The name Pendap is more identic with the region. The diversity of names refers to one meaning and reference, namely the traditional culinary origin of Bengkulu, which is made from the capa fish "a type of sea fish". Where this culinary is given spices mentioned in SubSection 2.2.2 and processed in the manner described in Sub-Section 2.2.3 and has a soft texture and flavorful typical of marine fish and tastes salty, sour, spicy mixed and tastes good like which is expressed in some of the lyrics of Ikan Pais, Rasonyo oii lemak nian 'It feels so good'. 


\subsection{Suggestions}

Talking about culture and nature in ecolinguistic studies can not be separated from the local genius which is a wealth of a nation, including in this case is a traditional culinary. The existence of traditional culinary Ikan Pais, both recipes and ways of making it, should be maintained amongthe massive production and import of fast food.

There are many other aspects that can be examined in connection with the traditional cuisine of Ikan Pais, for example an analysis of the name Pais which is phonologically similar to a type of cake in English, namely <pies> /paiz/, verbs used during the process of making Pais or comparison ecolinguistic with traditional Pendap. This research can be a reference for further research.

\section{REFERENCE}

Agung. 2011. Pengertian Studi Kepustakaan, (Online), (http://teori-ilmupemerintahan.blogspot.com/2011/06/pengertianstudi-kepustakaan.html, diakses 20 April 2014).

Anonim. Tidak ada tahun. Kota Bengkulu, (Online), (http://id.wikipedia.org/wiki/Kota_Bengk ulu, diakses 1 Desember 2018).

Anonim.Tidak ada tahun. Lagu Ikan Pais, (Online), (http://www.youtube.com/watch?v=YzU G0EFtjGA, diakses 20 Desember 2018).

Balai Penelitian Tanaman Palma. 2010. Kelapa, (Online), (http://balitka.litbang.deptan.go.id/kelapa, diakses 20 Desember 2018).

Djajasudarma, T. Fatimah. 2009. Semantik 1: Makna Leksikal dan Gramatikal. Bandung: PT Refika Aditama.

Fill, Alwin dan Peter Mühlhaüsler. 2001. The Ecolinguistitcs Reader: Language, Ecology and Environment. London: Continuum.
Hadi, Bambang Sutopo. 2013. Pandan Laut dapat Menyerap Limbah Industri, (Online),

(http://www.antaranews.com/berita/36655 8/pandan-laut-dapat-me-nyerap-limbahindustri, diakses 20 Desember 2018).

Haruman, M. Ganif. 2008. Pengertian Kebudayaan, (Online), (http://sobatbaru. blogspot.com/2008/04/pengertiankebudayaan.html, diakses 17 Oktober 2018).

Rezeki, Novandi. 2012. Lirik Lagu Ikan Pais, (Online), (http://novandirezeki.blogspot.com/2012/ 12/lirik-lagu-ikan-pais-lagu-daerah.html, diakses 20 Desember 2018).

Sudaryanto. 1988. Metode Linguistik: Metode dan Aneka Teknik Pengumpulan Data. Yogyakarta: Gadjah Mada University Press.

1993. Metode dan Aneka Teknik Analisis Bahasa: Pengantar Penelitian Wahana Kebudayaan Secara Linguistis. Yogyakarta: Duta Wacana University Press.

Suryadi, et al. 2002. Sistem Reduplikasi Bahasa Serawai. Jakarta: Pusat Bahasa, Departemen Pendidikan Nasional.

Van Valin, Robert D, Jr. \& Randy LaPolla. 1997. Syntax: Structure, Meaning \& Function. Cambridge: Cambridge University Press.

Wardiyono. 1997. 2014. Talas, (Online), (http://www.proseanet.org/prohati4/brows er.php?docsid=432, diakses 20 Desember 2018). 
